\title{
Analisis Faktor yang Mempengaruhi Corporate Social Responsibility Disclosure pada Perusahaan Pertambangan
}

\author{
Irena \\ Program Studi Akuntansi, Sekolah Tinggi Ilmu Ekonomi IBBI, Medan \\ Email:irenadarmawan@gmail.com
}

\begin{abstract}
Abstrak: Penelitian ini bertujuan untuk menguji dan menganalisis pengaruh profitabilitas, leverage, ukuran perusahaan dan ukuran dewan komisaris secara parsial terhadap corporate social responsibility disclosure (CSRD) pada perusahaan pertambangan yang terdaftar di Bursa Efek Indonesia (BEI) periode 2012-2016. Metode yang digunakan pada penelitian ini adalah deskriptif kuantitatif. Populasi dalam penelitian ini adalah seluruh perusahaan pertambangan yang terdaftar di BEI periode 2012-2016, yaitu 36 perusahaan. Berdasarkan metode seleksi sampel, maka jumlah perusahaan yang terpilih menjadi sampel penelitian adalah 25 perusahaan. Teknik analisis data yang digunakan adalah analisis regresi linear berganda.Hasil dari penelitian ini adalah ukuran perusahaan dan ukuran dewan komisaris berpengaruh signifikan secara parsial terhadap CSRD pada perusahaan pertambangan yang terdaftar di BEI periode 2012-2016.
\end{abstract}

Kata Kunci: Profitabilitas, Leverage, Ukuran Perusahaan, Ukuran Dewan Komisaris, Corporate Social Responsibility Disclosure.

Abstract: This research aims to examine and analyze the influence of profitability, leverage, company size and size of board of commissioner partially on CSRD in mining companies listed on the Indonesia Stock Exchange (IDX) period 2012-2016. The method used in this research is quantitative descriptive research. Population in this research is all mining companies listed in IDX period 2012-2016, which is 36 companies. Based on the sample selection method, the number of companies selected to be the research sample is 25 companies. The technique of data analysis used is multiple linear regression analysis. The result of this research is company size and size of board of commissioner had significant influencepartiallyto CSRD on mining companies listed on IDX period 2012 2016.

Keywords: Profitability, Leverage, Company Size, Size of Board of Commissioner, Corporate Social Responsibility Disclosure.

\section{PENDAHULUAN}

Perusahaan dalam menjaga eksistensinya, tidak terlepas dari dukungan masyarakat dan lingkungan dimana ketiganya memiliki hubungan saling memberi dan membutuhkan. Dampak positif dan dampak negatif pasti akan menyertai setiap kegiatan yang dilakukan oleh perusahaan. Pada umumnya dampak negatif terhadap lingkungan sekitar yang akan lebih mendominasi dari kegiatan bisnis suatu perusahaan. Oleh sebab itu, perusahaan harus selalu berkomitmen menjaga hubungan yang harmonis dengan lingkungan 
sekitarnya dengan tidak hanya berfokus pada aspek bisnis yang hanya menguntungkan perusahaan. Banyak kasus kerusakan lingkungan dan konflik sosial yang diakibatkan oleh kurangnya perhatian perusahaan dalam menjalankan bisnisnya, khususnya perusahaan pertambangan yang berada di Indonesia.

Bupati Banyuwangi memberikan teguran tertulis kepada PT Bumi Suksesindo (BSI), anak usaha PT Merdeka Copper Gold Tbk (MDKA) selaku pemegang izin pertambangan emas di Bukit Tumpang Pitu. Hal ini terkait dengan belum terealisasinya pembangunan enam dam yang telah dijanjikan oleh PT Bumi Suksesindo sesuai dengan dokumen lingkungan. Dampaknya, lumpur serta sampah terbawa ke hilir hingga ke Sungai katak serta ke Pantai Pulau Merah ketika hujan deras (Priyasidharta, 2016).

Dikeluarkannya izin operasi produksi tambang kepada PT Citra Palu Minerals (CPM) yang merupakan anak usaha PT Bumi Resources Tbk (BRMS) mengakibatkan Menteri Energi dan Sumber Daya Mineral (ESDM) digugat oleh Wahana Lingkungan Hidup Indonesia (WALHI. PT Citra Palu Minerals memilki total lahan lima blok seluas 85.180 hektare di Kabupaten Luwu Utara, Sulawesi Selatan dan Palu, Sulawesi Tengah. Keputusan Menteri ESDM tersebut dinilai melanggar Undang-Undang No. 32 Tahun 2009 tentang Perlindungan dan Pengelolahan Lingkungan Hidup. Sebab, terdapat 18.000 hektare dari total izin 85.180 hektare yang merupakan hutan primer dan taman hutan rakyat. Selain itu, sebelum adanya izin perluasan lahan PT Citra Palu Minerals juga telah memberikan dampak kerusakan lingkungan akibat operasi perusahaan (Indra, 2018).

PT Freeport Indonesia (PTFI) dinyatakan melakukan dua pelanggran oleh Badan Pemeriksa Keuangan (BPK). Kedua pelanggaran ini merugikan negara hingga Rp 455 triliun. Pelaggaran pertama yang dilakukan oleh PT Freeport Indonesia adalah penggunaan kawasan hutan lindung seluas minimal 4.535 hektare dalam kegiatan operasional tanpa izin pakai. Pelanggaran yang kedua adalah terjadinya perubahan ekosistem akibat pembuangan limbah operasional penambangan (tailing) Freeport di sungai, hutan, muara dan telah mencapai kawasan laut (Kholiqa, 2018).

Berbagai masalah yang ditimbulkan perusahaan seperti polusi, limbah pabrik, eksploitasi sumber daya alam, tenaga kerja dan keamanan produk menjadi berita utama. Pengungkapan yang transparan, akuntabel serta tata kelola perusahaan yang baik (good corporate governance) kini menjadi tuntutan masyarakat yang paling besar terhadap perusahaan, mengharuskan perusahaan agar bertanggung jawab atas dampak dari aktivitas bisnisnya kepada masyarakat disekitar perusahaan pada khusunya dan masyarakat luas pada umumnya. Banyak tindakan yang dapat dilakukan perusahaan dalam memberikan tanggung jawabnya kepada masyarakat salah satunya adalah tanggung dengan melaksanakan corporate social responsibility (CSR). Dengan penerapan dan penyampaian informasi yang relevan mengenai corporate social responsibility disclosure (CSRD) kepada masyarakat luas, akan meningkatkan kepercayaan seluruh pemangku kepentingan yang tidak hanya masyarakat terhadap perusahaan yang pada akhirnya perusahaan akan mampu memaksimalkan kekuatan keuangannya dalam jangka panjang.

Pentingnya corporate social responsibility disclosure telah menarik minat para peneliti untuk meneliti terkai dengan praktik dan dorongan perusahaan dalam melaksanakan corporate social responsibility, khusunya di Indonesia. Selain itu, terdapat banyak faktor yang dipertimbangkan perusahaan dalam mengungkapkan tanggung jawab sosialnya. 
Profitabilitas merupakan salah satu faktor yang banyak diteliti dalam pengungkapan tanggung jawab sosial. Penelitian yang dilakukan oleh (Sunaryo dan Mahmud, 2016) pada perusahaan manufaktur yang listing di BEI tahun 2010-2013, menemukan hubungan positif antara profitabilitas dengan pengungkapan tanggung jawab sosial. Perusahaan dengan profitabilitas yang tinggi akan mendorong para manajer untuk memberikan informasi yang lebih rinci tentang perusahaan. Sementara itu, (Deitiana, 2015) juga melakukan penelitian pada perusahaan pertambangan yang terdaftar di BEI periode 20062012 namun, hasilnya adalah profitabilitas tidak berpengaruh terhadap pengungkapan tanggung jawab sosial perusahaan.

Pengungkapan tanggung jawab sosial juga dipengaruhi oleh leverage. Penelitian (Felicia dan Ramini, 2015) pada perusahaan manufaktur yang terdaftar di BEI periode 2010-2012 menunjukkan hasil bahwa leverage berpengaruh terhadap pengungkapan tanggung jawab sosial. Sedangkan, pada penelitian yang dilakukan oleh (Deitiana, 2015) menunjukkan bahwa tidak berepengaruhnya leverage terhadap pengungkapan tanggung jawab sosial.

Ukuran perusahaan juga merupakan salah satu faktor yang digunakan untuk menjelaskan pengungkapan tanggung jawab sosial perusahaan. Hasil penelitian (Riantani dan Nurzamzam, 2015) pada perusahaan rokok yang terdaftar di BEI periode 2007-2011 menunjukkan adanya hubungan anatara ukuran perusahaan dengan pengungkapan tanggung jawab sosial perusahaan. Namun, hasil penelitian yang dilakukan oleh (Sunaryo dan Mahmud, 2016) pada perusahaan manufaktur yang listing di BEI tahun 2010-2013 menunjukkan tidak adanya hubungan antara ukuran perusahaan terhadap pengungkapan tanggung jawab sosial.

Selain itu, Ukuran dewan komisaris juga mempengaruhi pengungkapan tanggung jawab sosial perusahaan. Dengan wewenang yang dimiliki, dewan komisaris dapat memberikan pengaruh yang cukup kuat untuk menekan manajemen agar mengungkapakan tanggung jawab sosial perusahaan. Penelitian yang dilakukan oleh (Deitiana, 2015) pada perusahaan pertambangan yang terdaftar di BEI periode 2006-2012, menunjukkan hasil berpengaruhnya ukuran dewan komisaris terhadap pengungkapan tanggung jawab sosial perusahaan. Namun, penelitian (Krisna dan Suhardianto, 2016) tidak menunjukkan bukti adanya pengaruh ukuran dewan komisaris terhadap pengungkapan tanggung jawab sosial.

Penelitian-penelitian yang telah dilakukan mengenai faktor-faktor yang mempengaruhi corporate social responsibility disclosure memiliki hasil yang berbeda. Penelitian ini dilakukan untuk menganalisis kembali hasil penelitian terdahulu tentang faktor-faktor apa saja yang mempengaruhi corporate social responsibility disclosure. Yang membedakan penelitian ini dengan penelitian sebelumnya adalah periode dalam penelitian ini lebih baru, yaitu 2012-2016. Objek yang diteliti adalah perusahaan pertambangan, karena peneliti beranggapan bahwa perusahaan pertambangan memiliki kesinambungan dengan alam, di mana mulai dari bahan baku, proses produksi, hingga produk yang dijual tidak terlepas dari lingkungan yang ada.

\section{KAJIAN TEORI}

Teori Agensi. Pada teori ini dinyatakan bahwa hubungan keagenan timbul ketika pihak prinsipal menyewa agen untuk melakukan beberapa layanan atas nama mereka yang melibatkan pendelegasian beberapa otoritas pembuatan keputusan kepada agen (Jensen 
dan Meckling, 1976). Diasumsikan bahwa semua individu bertindak atas kepentingan mereka sendiri, sehingga terjadi konflik kepentingan dalam hubungan keagenan.

Para investor yang bertindak sebagai prinsipal dianggap hanya berkeinginan untuk mendapatkan pengembalian yang besar atas apa yang telah mereka investasikan. Di lain pihak, para manajer sebagai agen memiliki keinginan untuk mendapatkan reward keungan yang sesuai dengan apa yang telah mereka berikan kepada para prinsipal.

Pengungkapan tanggung jawab sosial perusahaan dilakukan oleh manajer sebagai agen untuk bertanggung jawab kepada pihak prinsipal. Corporate social responsibility disclosure diharapkan dapat meningkatkan reputasi perusahaan, dengan demikian kekayaan pemegang saham juga akan meningkat (Chintrakarn et al., 2016) dan konflik keagenan akan dapat terselesaikan.

Teori Legitimasi. Teori legitimasi didasari atas kontrak sosial antara perusahaan dengan masyarakat dimana, perusahaan wajib untuk mematuhi norma, nilai dan perraturan sosial yang berlaku di masyarakat (Dowling dan Pfeffer, 1975). Legitimasi merupakan sistem tata kelolah perusahaan yang berpusat kepada keberpihakan terhadap individu, masyarakat dan pemerintah. Perusahaan menyadari bahwa adanya hubungan yang baik dengan masyarakat sangat dibutuhkan dalam keberlanjutan hidup perusahaan. Dampak negatif seperti kerusakan lingkungan yang ditimbulkan oleh aktivitas perusahaan, khususnya pertambangan yang berhubungan langsung dengan sumber daya alam dapat dirasakan masyarakat. Perusahaan dapat menggunakan pengungkapan untuk menunjukkan perhatiannya terhadap nilai-nilai masyarakat, atau untuk mengalihkan perhatian masyarakat akan efek negatif dari aktivitas perusahaan (Riantani dan Nurzamzam, 2015).

Melalui legitimasi, perusahaan dapat mengurangi dan menghindari legitimacy gap, mengembangkan usaha terutama terkait dengan memposisikan diri di tengah lingkungan masyarakat yang semakin berkembang sehingga hal ini dapat dijadikan sebagai sarana penetapan strategi perusahaan. Oleh karena itu, teori legitimasi merupakan salah satu teori yang mendasari corporate social responsibility disclosure yang merupakan wujud dari tanggung jawab perusahaan untuk masyarakat dan lingkungan.

Corporate Social Responsibility (CSR). Tanggung jawab sosial perusahaan atau Corporate Social Responsibility adalah komitmen perusahaan untuk menjamin keberlanjutannya tidak hanya berorientasi pada pencapaian dari segi finansial namun juga menjaga hubungan yang serasi dan seimbang dengan nilai, norma, budaya masyarakat setempat dan lingkungan (Lindawati dan Puspita, 2015).

Di Indonesia, corporate social responsibility disepadankan dengan Tanggung Jawab Sosial dan Lingkungan (TJSL) dan diatur dalam Undang-Undang Nomor 40 Tahun 2007, dimana corporate social responsibility atau Tanggung Jawab Sosial dan Lingkungan merupakan komitmen Perseroan untuk berperan serta dalam pembangunan ekonomi berkelanjutan guna meningkatkan kualitas kehidupan dan lingkungan yang bermanfaat, baik bagi Perseroa sendiri, komunitas setempat, maupun masyarakat pada umumnya. Selanjutnya, Undang-Undang Nomor 25 Tahun 2007 mendefinisikan corporate social responsibility sebagai tanggung jawab yang melekat pada setiap perusahaan dan penanaman modal untuk tetap menciptakan hubungan yang serasi, seimbang, dan sesuai dengan lingkungan, nilai, norma, dan budaya masyarakat setempat. 
Saat ini keadaan keuangan dan nilai perusahaan tidak menjadi jaminan keberlanjutan dari sebuah perusahaan. Untuk itu dengan mekanisme dari corporate social responsibility yang menjelaskan bahwasannya perusahaan harus bertanggung jawab kepada seluruh pemangku kepentingan (stakeholders), bukan hanya kepada para investor.

Profitabilitas. Profitabilitas merupakan kemampuan perusahaan untuk memperoleh laba atau menghasilkan keuntungan yang berhubungan dengan penjualan, aset maupun laba bagi modal sendiri. Melalui rasio profitabilitas akan memberikan jawaban akhir tentang efektivitas pengelolahan perusahaan, sebab rasio ini memberikan gambaran mengenai efektivitas pengelolahan perusahaan. Efektivitas manajemen disini dilihat dari laba yang dihasilkan terhadap penjualan dan investasi perusahaan.

Menurut teori keagenan, ketika perusahaan memperoleh laba yang besar maka, informasi sosial akan semakin luas diungkapakan oleh perusahaan (Bowman dan Haire 1976). Hal ini dilakukan perusahaan agar meminimalkan biaya keagenan. Semakin besar tingkat profitabilitas yang diperoleh perusahaan maka semakin luas kebebasan dan fleksibilitas manajemen dalam pelaksanaan dan pengungkapan corporate social responsibility. Profitabilitas akan memberikan kepercayaan kepada perusahaan untuk mengungkapkan corporate social responsibility-nya (Asmeri et al., 2017).

Leverage. Melalui rasio leverage, dana perusahaan yang berasal dari utang dan tingkat resiko tidak terbayarnya utang tersebut dapat diketahui. Menurut teori agensi, tingkat rasio leverage yang besar akan membuat perusahaan lebih luas dalam mengungkapkan informasi sebab, lebih besarnya alokasi biaya keagenan perusahaan tersebut (Jensen dan Mackling, 1976).

Berdasarkan teori (Belkaoui dan Karpik, 1989) menyatakan hal sebaliknya dimana, ketika level leverage perusahaan tinggi ada peluang perusahaan itu akan tidak mematuhi kontrak kreditnya yang mengakibatkan perusahaan akan melaporkan laba sekaarang lebih besar lagi. Perusahaan yang memilki tingkat leverage besar akan melaporkan laba sekarang lebih besar dibandingkan yang akan datang. Manajemen dengan leverage tinggi akan mengurangi pengungkapan tanggung jawab sosial perusahaan agar dapat melaporkan laba sekarang yang lebih tinggi untuk menghindari pemeriksaan oleh kreditur.

Ukuran Perusahaan. Menurut ukurannya, perusahaan dibagi menjadi dua yaitu perusahaan besar dan perusahaan kecil. Umunya, perusahaan besar akan mengungkapkan informasi lebih banyak daripada perusahaan kecil (Jensen dan Meckling, 1976). Sebab, perusahaan besar akan menghadapi resiko politis yang lebih besar, yaitu tekanan untuk melakukan pertanggungjawaban sosial daripada perusahaan kecil. Selain itu, dengan dilaksanakannya corporate social responsibility oleh perusahan merupakan media untuk mendapatkan dukungan dari pemangku kepentingan. Pengungkapan tanggung jawab sosial merupakan alat manajerial yang digunakan perusahaan untuk menghindari konflik sosial dan lingkungan.

Ukuran Dewan Komisaris. Ukuran dewan komisaris di dalam perusahaan dapat memberikan pengaruh terhadap pengungkapan tanggung jawab sosial perusahaan, sebab dewan komisaris merupakan pelaksana tertinggi dalam perusahaan. Dewan komisaris dapat memberikan tekanan kepada manajemen perusahaan untuk melaksanakan dan 
menginformasikan corporate social responsibility, sehingga perusahaan yang mempunyai jumlah dewan komisaris yang lebih banyak diasumsikan mengungkapkan corporate social responsibility lebih luas juga (Deitiana, 2015). Melalui tekanan yang diberikan oleh dewan komisaris untuk mengungkapkan corporate social responsibility, maka perusahaan akan mendapatkan legitimasi dari para pemangku kepentingan yang pada akhirnya akan meningkatkan nilai perusahaan.

\section{Kerangka Pemikiran}

Gambar 1. Kerangka Pemikiran

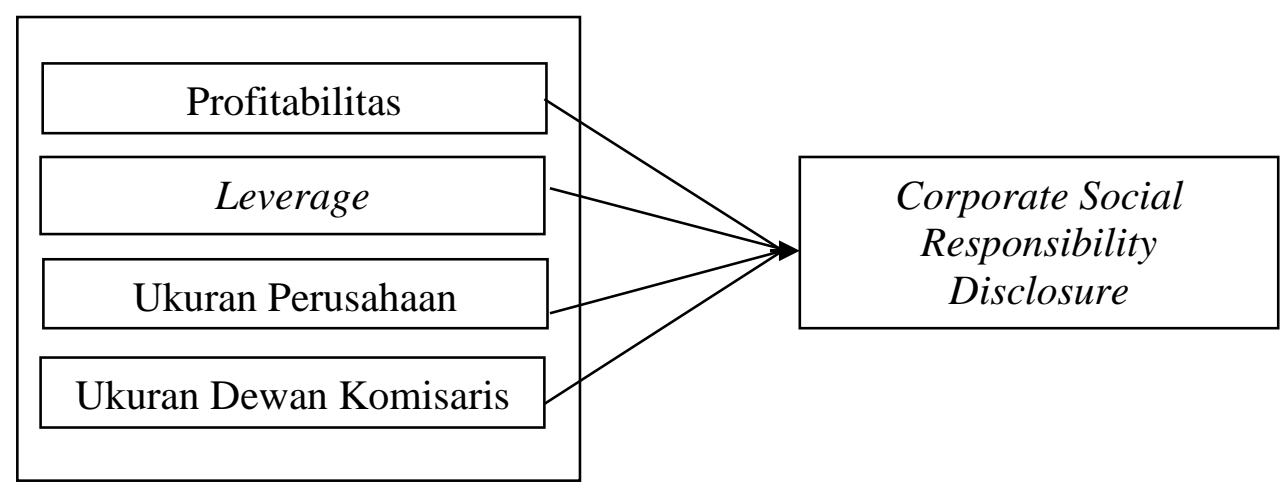

Hipotesis dari penelitian ini dirumuskan sebagai berikut:

Profitabilitas, leverage, ukuran perusahaan, dan ukuran dewan komisaris berpengaruh secara parsial terhadap corporate social responsibility disclosure pada perusahan pertambangan yang terdaftar di Bursa Efek Indonesia periode 2012-2016.

\section{METODOLOGI}

Metode pada penelitian ini adalah penelitian deskriptif kuantitatif yang digunakan untuk menganalisis data dengan cara mendeskripsikan data yang telah terkumpul sebagaimana adanya.

Variabel Dependen. Variabel dependen yang digunakan pada penelitian ini adalah Corporate Social Responsibility Disclosure. Defenisi operasional corporate social responsibility disclosure yang diterapkan pada penelitian ini adalah banyaknya item-item pengungkapan tanggung jawab sosial yang diungkapkan dalam laporan tahunan yang dipublikasikan oleh perusahaan. Variabel pengungkapan sosial perusahaan diukur menggunakan metode pengkodifikasian teks dan ciri-ciri yang sama dan ditulis dalam berbagai kelompok tergantung pada kriteria yang telah ditentukan (content analysis). Check list dilakukan untuk setiap item yang diungkapkan oleh perusahaan.

Corporate social responsibility disclosure adalah data yang dipublikasikan oleh perusahaan yang berhubungan dengan aktifitas sosial perusahaan yaitu, tiga faktor utama yang terdiri dari ekonomi, lingkungan serta sosial. Pengungkapan tanggung jawab sosial yang diungkapkan oleh perusahan meliputi tiga belas item lingkungan, tujuh item energi, delapan item kesehatan dan keselamatan kerja, dua puluh sembilan item lain-lain tenaga 
kerja, sepuluh item produk, sembilan item keterlibatan masyarakat, dan dua item umum (Sembiring, 2005). Jika diantara item pengungkapan tersebut terdapat pada laporan tahunan perusahaan, maka akan diberi skor 1 . Namun, apabila item pengungkapan tersebut tidak terdapat pada laporan tahunan perusahaan, maka diberi skor 0. Rumus indeks pengungkapan corporate social responsibility pada penelitian ini, yaitu

$$
C S R I j=\frac{\sum x i j}{n j}
$$

Keterangan:

CSRIj : Corporate Social Responsibility Disclosure Index perusahaan j

$\mathrm{Xi} \quad$ : nilai $1=$ item i diungkapkan; $0=$ item i tidak diungkapkan Maka, $0<$ CSRIj $<1$

nj : Jumlah item untuk perusahaan $\mathrm{j}, \mathrm{nj}<78$

(Sumber: Sembiring, 2005)

Profitabilitas. Profitabilitas pada penelitian ini diukur dengan menggunakan Return on Asset (ROA). Melalui ROA dapat mencerminkan seberapa besar pengembalian yang dihasilkan atas setiap rupiah uang yang ditanamkan dalam bentuk aset. Rasio ini dapat dihitung dengan rumus:

$$
\text { Return on Asset }(R O A)=\frac{\text { Laba Setelah Pajak }}{\text { Total Aset }}
$$

(Sumber: Riantani and Nurzamzam, 2015)

Leverage. Leverage diukur menggunakan rasio Debt to Equity Ratio (DER), yaitu rasio yang memperlihatkan seberapa besar dari keseluruhan jumlah kewajiban perusahaan akan dijamin oleh ekuitas. Rasio ini dapat dihitung dengan rumus:

$$
\text { Debt to Equity Ratio }(D E R)=\frac{\text { Total Kewajiabn }}{\text { Total Ekuitas }}
$$

(Sumber: Riantani and Nurzamzam, 2015)

Ukuran Perusahaan. Ukuran perusahaan pada penelitian ini diukur berdasarkan total aset yang dimiliki perusahaan, karena nilai aset relatif lebih stabil dan dapat menggambarkan ukuran perusahaan. Total aset akan ditransformasikan dalam bentuk logaritma natural.

$$
\text { SIZE = Log Natural (Total Aset) }
$$

(Sumber: Deitiana, 2015)

Ukuran Dewan Komisaris. Ukuran dewan komisaris diukur dengan melihat banyaknya jumlah anggota dewan komisaris dalam perusahaan (Krisna dan Suhardianto, 2016). Jumlah dewan komisaris yang ada di perusahaan akan mencerminkan objektivitas dalam menilai kebijakan yang dibuat perusahaan. 


\section{$U D K=\sum$ Dewan Komisaris Perusahaan}

(Sumber: Krisna dan Suhardianto, 2016)

Jenis dan Sumber data Penelitian. Jenis dan sumber data penelitian ini adalah kuantitatif dan sekunder. Data ini diperoleh dari laporan tahunan perusahaan pertambangan yang terdaftar di Bursa Efek Indonesia selama periode 2012-2016 yang diterbitkan di situs www.idx.co.id.

Populasi dan Sampel Penelitian. Populasi dalam penelitian ini adalah seluruh perusahaan pertambangan yang terdaftar di BEI periode 2012-2016, yaitu 36 perusahaan. Metode pengambilan sampel pada penelitian ini merupakan metode seleksi sampel dengan mengambil sampel yang telah ditentukan sebelumnya berdasarkan tujuan penelitian dengan kriteria.

Tabel 2. Kriteria Pemilihan Sampel

\begin{tabular}{l|l|c}
\hline No & \multicolumn{1}{|c}{ Keterangan } & Jumlah Perusahaan \\
\hline 1 & $\begin{array}{l}\text { Perusahaan pertambangan yang terdaftar di BEI periode } \\
\text { 2012-2016. }\end{array}$ & 36 \\
\hline 2 & $\begin{array}{l}\text { Perusahaan pertambangan yang tidak mempublikasikan } \\
\text { laporan tahunan dan CSRD periode 2012-2016. }\end{array}$ & $(11)$ \\
\hline Total Sampel & 25 \\
\hline Total Observasi (5 tahun amatan) & 125 \\
\hline
\end{tabular}

(Sumber: Data Diolah, 2018)

Berdasarkan kriteria tersebut, maka jumlah perusahaan yang terpilih menjadi sampel penelitian adalah 25 perusahaan. Angka tahun amatan pada penelitian ini adalah 5 tahun, sehingga jumlah observasi dalam penelitian adalah 125 observasi.

\section{HASIL DAN PEMBAHASAN}

Analisis Regresi Linear Berganda. Analisis regresi linear berganda bertujuan untuk mengetahui hubungan antara variabel dependen berupa corporate social responsibility disclosure (CSRD) dengan variabel independen berupa profitabilitas, leverage, ukuran perusahaan dan ukuran dewan komisaris. Hasil analisis linear regresi berganda dapat dilihat sebagai berikut:

\section{Structural Equations}

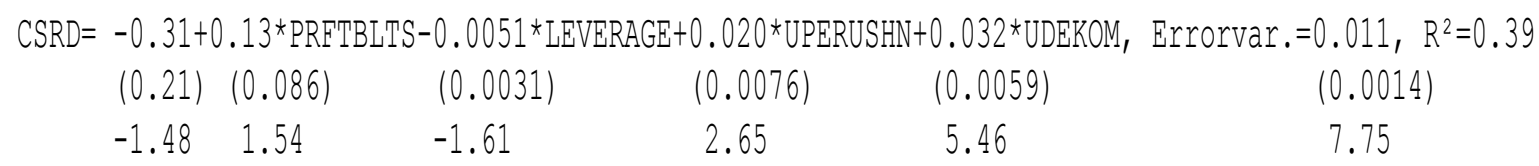

(Sumber: Data Diolah, 2018) 

berikut:

Berdasarkan hasil analisis maka diperoleh persamaan regresi linier berganda sebagai

$$
Y=-0,31+0,13 X_{1}-0,0051 X_{2}+0,020 X_{3}+0,032 X_{4}+e
$$

Hasil tersebut dapat dijelaskan sebagai berikut:

Konstanta sebesar -0,31 menyatakan bahwa jika nilai dari variabel profitabilitas, leverage, ukuran perusahaan, dan ukuran dewan komisaris adalah 0 maka, indeks dari corporate social responsibility disclosure sebesar -0,31.

Koefisien regresi profitabilitas (X1) sebesar 0,13. Artinya profitabilitas menunjukkan pengaruh positif terhadap tingkat corporate social responsibility disclosure. Hal ini berarti bahwa, setiap peningkatan satu satuan pada rasio profitabilitas, maka akan menambah indeks corporate social responsibility disclosure sebesar 0,13 dengan asumsi variabel lain tetap.

Koefisien regresi leverage (X2) sebesar -0,0051. Artinya leverage menunjukkan pengaruh negatif terhadap tingkat corporate social responsibility disclosure. Hal ini berarti bahwa, setiap peningkatan satu satuan pada rasio leverage, maka akan mengurangi indeks corporate social responsibility disclosure sebesar -0,005 dengan asumsi variabel lain tetap.

Koefisien regresi ukuran perusahaan (X3) sebesar 0,020. Artinya ukuran perusahaan menunjukkan pengaruh positif terhadap tingkat corporate social responsibility disclosure. Hal ini berarti bahwa, setiap peningkatan satu satuan pada rasio ukuran perusahaan, maka akan menambah indeks corporate social responsibility disclosure sebesar 0,020 dengan asumsi variabel lain tetap.

Koefisien regresi untuk ukuran dewan komisaris (X4) sebesar 0,032. Artinya ukuran dewan komisaris menunjukkan pengaruh positif terhadap tingkat corporate social responsibility disclosure. Hal ini berarti bahwa, setiap peningkatan satu satuan pada rasio ukuran dewan komisaris, maka akan menambah indeks corporate social responsibility disclosure sebesar 0,032 dengan asumsi variabel lain tetap.

Uji Regresi Parsial (Uji t). Uji Regresi Parsial (Uji t) dilakukan untuk mengetahui hubungan dari masing-masing variabel bebas terhadap variabel terikatnya. Berikut adalah gambar hasil uji regresi parsial. 
Gambar 2. Hasil Uji Regresi Parsial (Uji t) Menggunakan Lisrel

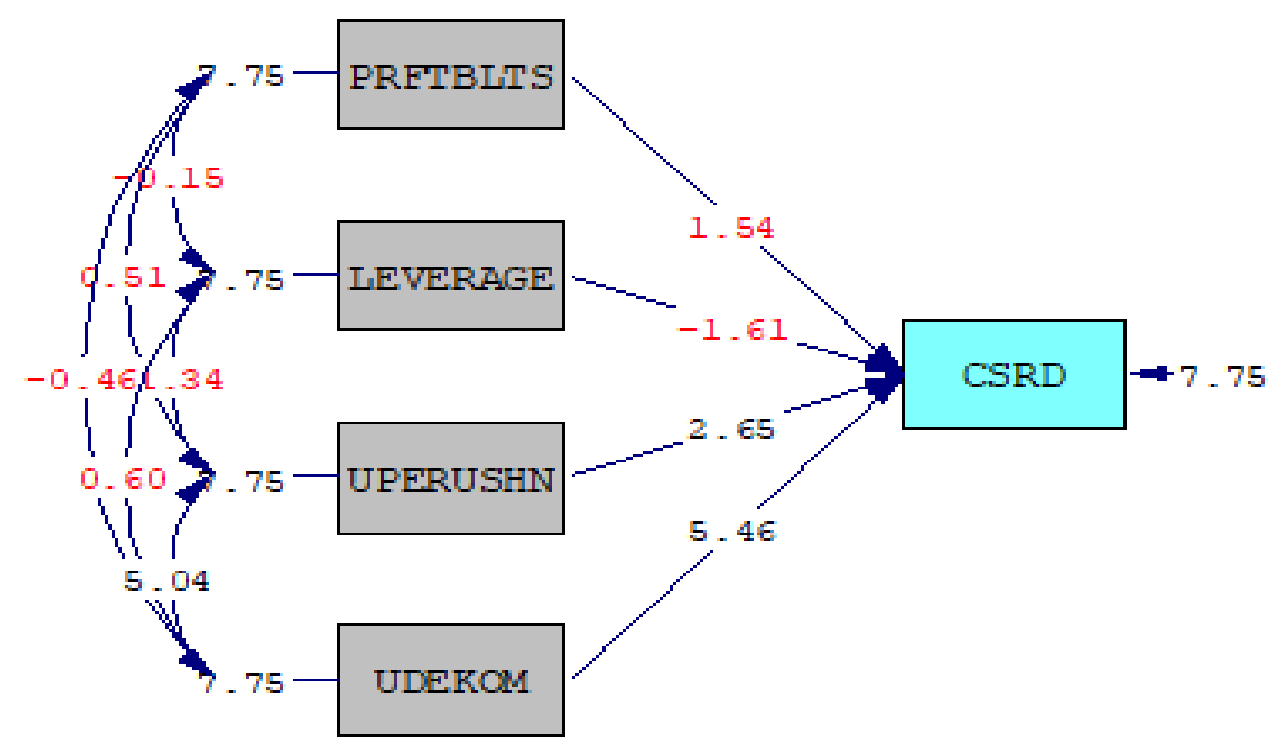

Chi-Square=0.00, df=0, P-value=1.00000, RMSEA $=0.000$

(Sumber: Data Diolah, 2018)

Variabel profitabilitas berpengaruh negatif dan tidak signifikan terhadap corporate social responsibility disclosure, hal ini terlihat dari nilai t-hitung untuk variabel profitabilitas (X1) adalah 1,54<t-tabel 1,979. Artinya bahwa profitabilitas tidak berpengaruh signifikan secara parsial terhadap corporate social responsibility disclosure pada perusahaan pertambangan yang terdaftar di BEI.

Variabel leverage berpengaruh negatif dan tidak signifikan terhadap corporate social responsibility disclosure, hal ini terlihat dari nilai t-hitung untuk variabel leverage adalah $-1,61<\mathrm{t}$-tabel 1,979. Artinya bahwa leverage tidak berpengaruh signifikan secara parsial terhadap corporate social responsibility disclosure pada perusahaan pertambangan yang terdaftar di BEI.

Variabel ukuran perusahaan berepngaruh signifikan terhadap corporate social responsibility disclosure, hal ini terlihat dari nilai t-hitung untuk variabel ukuran perusahaan adalah 2,65 > t-tabel 1,979. Artinya bahwa ukuran perusahaan berpengaruh signifikan secara parsial terhadap corporate social responsibility disclosure pada perusahaan pertambangan yang terdaftar di BEI.

Variabel ukuran dewan komisaris berpengaruh signifikan terhadap corporate social responsibility disclosure, hal ini terlihat dari nilai t-hitung untuk variabel ukuran dewan komisaris adalah 5,46>t-tabel 1,979 artinya bahwa ukuran dewan komisaris berpengaruh signifikan secara parsial terhadap corporate social responsibility disclosure pada perusahaan pertambangan yang terdaftar di BEI.

Variabel ukuran dewan komisaris secara parsial lebih berpengaruh dan dominan dibandingkan dengan variabel profitabilitas, leverage dan ukuran perusahaan. Artinya, 
variabel ukuran dewan komisaris lebih banyak berpengaruh dalam mengungkapkan corporate social responsibility pada perusahaan pertambangan yang terdaftar di BEI.

\section{Uji Koefisien Determinasi}

Structural Equations

CSRD $=-0.31+0.13 *$ PRFTBITS $-0.0051 *$ LEVERAGE $+0.020 *$ UPERUSHN $+0.032 *$ UDEKOM, Errorvar. $=0.011$, $R^{2}=0.39$

(Sumber: Data Diolah, 2018)

Berdasarkan hasil pengujian di atas menunjukkan bahwa R Square adalah sebesar 0,39 . Ini berarti bahwa hubungan antara profitabilitas, leverage, ukuran perusahaan dan ukuran dewan komisaris dengan corporate social responsibility disclosure 39\%., sisanya $61 \%$ dipengaruhi oleh variabel independen lainnya.

\section{PEMBAHASAN}

Pengaruh profitabilitas secara parsial terhadap CSRD. Berdasarkan hasil penelitian, profitabilitas tidak menunjukkan pengaruh yang signifikan terhadap corporate social responsibility disclosure. Artinya, besar kecilnya profit yang dihasilakan perusahaan tidak mempengaruhi luas corporate social responsibility disclosur esecara signifikan pada perusahaan pertambangan yang terdaftar di BEI. Hasil penelitian ini sejalan dengan hasil penelitian tidak adanya pengaruh tingkat profitabilitas perusahaan kepada luas pengungkapan corporate social responsibility. Hasil penelitian tersebut dilakukan oleh (Amalia, 2013) pada perusahaan yang listing di Bursa Efek Indonesia Tahun 2009 dan 2010, (Deitiana, 2015), (Dewi dan Suaryana, 2015) di sektor pertambangan, (Nurfadilah dan Sagara, 2015) serta (Manurung dan Muid, 2015) pada sektor manufaktur.

Teori agensi yang menyatakan bahwa besarnya kebebasan suatu perusahaan dalam mengungkapkan tanggung jawab sosial perusahaannya dipengaruhi oleh tingkat profitabilitas dari perusahaan tersebut tidak didukung pada penelitian ini. Tingkat profitabilitas yang tinggi pada perusahaan belum tentu lebih banyak melaksanakan dan mengungkapkan kegiatan sosialnya, karena perusahaan lebih tertarik pada laba. Perusahaan pertambangan yang terdaftar di BEI beranggapan bahwa dengan melaksanakan dan mengungkapkan tanggung jawab sosial, hanya akan menambah beban dan pengeluaran yang pada akhirnya akan mengakibatkan profitabilitas perusahaan menurun.

Legitimasi dari para pemangku kepentingan yang dapat bertambah melalui pengungkapan tanggung jawab sosial perusahaan juga tidak mempengaruhi perusahaan, khususnya sektor pertambangan untuk lebih memperhatikan tanggung jawab sosial perusahaannya. Sebab, perusahaan menganggap bahwa legitimasi dari para pemangku kepentingan, khususnya para investor dan kreditor hanya mementingkan tingkat proftabilitas yang diberikan oleh perusahaan. Hal ini didukung juga dengan argumentasi 
yang menyatakan bahwa ketika perusahaan tersebut memiliki laba yang besar, manajemen beranggapan tidak diperlukannya laporan yang dapat mengganggu informasi kesuksesan keuangan perusahaan. Tetapi, jika perusahaan tersebut memiliki laba yang rendah maka, manajemen berharap para pengguna laporan akan mendapatkan informasi yang baik dari kinerja perusahaan.

Pengaruh leverage secara parsial terhadap CSRD. Berdasarkan hasil penelitian, variabel leverage tidak menunjukkan pengaruh yang signifikan terhadap corporate social responsibility disclosure. Artinya, tingkat leverage tidak mempengaruhi luas corporate social responsibility disclosure secara signifikan pada perusahaan pertambangan yang terdaftar di BEI. Hail penelitian ini mendukung penelitian yang dilakukan oleh (Chauhan dan Amit, 2014), (Manurung dan Muid, 2015), (Maulana dan Yuyetta,2014), (Hidayat, 2017) serta, (Pradnyani dan Sisdyani, 2015) tidak menunjukkan pengaruh leverage terhadap pengungkapan corporate social responsibility.

Hasil penelitian ini tidak mendukung pendapat teori agensi yang menyatakan bahwa perusahaan dengan rasio leverage yang lebih tinggi akan mengungkapkan lebih banyak informasi mengenai aktivitas sosial perusahaan untuk mengurangi biaya keagenan. Sebaliknya, perusahaan dengan tingkat leverage yang tinggi kemungkinan besar perusahaan tersebut akan mengalami kontrak utang, maka untuk mengurangi kemungkinan perusahaan melanggar perjanjian utang tersebut perusahaan akan berusaha melaporkan laba sekarang lebih tinggi (Belkaoui dan Karpik, 1989).

Pelaksanaan dan pengungkapan tanggung jawab sosial perusahaan dianggap manajer sebagai beban perusahaan yang dapat mengurangi laba perusahaan. Untuk itu, perusahaan memilih metode akuntansi yang akan memaksimalkan laba dengan mengurangi segala biaya, termasuk biaya untuk melaksanakan dan mengungkapkan tanggung jawab sosial perusahaannya. Sesuai dengan pendapat ini, hasil penelitian membuktikan bahwa perusahaan pertambangan yang terdaftar di BEI tidak memperhatikan faktor leverage dalam mengungkapkan tanggung jawab sosial perusahaan mereka.

Pengaruh ukuran perusahaan secara parsial terhadap CSRD. Berdasarkan hasil penelitian, variabel ukuran perusahaan menunjukkan pengaruh yang signifikan terhadap corporate social responsibility disclosure. Artinya, besar kecilnya ukuran perusahaan mempengaruhi luas corporate social responsibility disclosure secara signifikan pada perusahaan pertambangan yang terdaftar di BEI. Penelitian ini sejalan dengan hasil penelitian yang dilakukan oleh (Amalia, 2013), (Gunawan, 2013), (Chauhan dan Amit, 2014), (Sari dan Rani, 2015) serta, (Hidayat, 2017) dimana dapat dibuktikan adanya pengaruh dari besar kecilnya ukuran perusahaan terhadap pengungkapan CSR di berbagai sektor perusahan.

Teori agensi menyatakan bahwa biaya keagenan yang dikeluarkan oleh perusahaan yang ukrannya lebih besar akan lebih besar pula. Untuk mengurangi biaya keagenan tersebut perusahaan akan mengungkapkan informasi yang lebih luas (Sembiring, 2005). Serta, perusahaan besar pastinya memiliki sumber daya yang lebih besar, sehingga akan lebih mampu membiayai pelaksanaan dan pengungkapan tanggung jawab sosial perusahaan.

Ukuran suatu perusahaan dapat menunjukkan seberapa besar pula resiko politis ataupun tekanan yang akan dihadapi perusahaan tersebut. Semakin besar ukuran suatu 
perusahaan maka, semakin besar pula pengaruh yang diberikan perusahaan terhadap para pemangku kepentingan. Oleh karena itu, perusahaan yang lebih besar akan melaksanakan dan mengungkapkan tanggung jawab sosial perusahaannya dengan lebih luas untuk mendapatkan legitimasi ataupun dukungan para pemangku kepentingan.

Pengaruh ukuran dewan komisaris secara parsial terhadap CSRD. Hasil penelitian ini menunjukkan variabel ukuran dewan komisaris berpengaruh signifikan terhadap corporate social responsibility disclosure. Artinya, besar kecilnya ukuran dewan komisaris mempengaruhi luas corporate social responsibility disclosure secara signifikan pada perusahaan pertambangan yang terdaftar di BEI. Penelitian ini mendukung hasil penelitian yang dilakukan oleh (Amalia, 2013), (Budiman, 2015), Manurung dan Muid (2015), (Purbowati dan Mutiarni, 2017) serta, (Solikhah dan Winarsih, 2016) dimana ukuran dewan komisaris mempengaruhi pengungkapan corporate social responsibility oleh perusahaan.

Hasil penelitian ini juga didukung dengan pendapat (Deitiana, 2015) yang menyatakan perusahaan yang memiliki jumlah dewan komisaris yang lebih banyak akan mengungkapkan corporate social responsibility lebih banyak juga sebab, dewan komisaris dapat memberikan tekanan kepada manajemen perusahaan untuk mengungkapkan tanggung jawab sosial perusahaannya. Dewan komisaris yang merupakan wakil shareholder dalam perusahaan pasti menginginkan peningkatan citra serta nilai perusahaan yang baik.

Dengan wewenang untuk mengawasi, memberikan petunjuk serta arahan pada pengelolahan perusahaan, jumlah dewan komisaris yang lebih banyak akan memberikan pengaruh yang lebih besar kepada manajemen untuk melaksanakan dan megungkapkan tanggung jawab sosial perusahaan. Melalui pengungkapan tanggung jawab sosial, perusahaan dapat meningkatkan legitimasi para pemangku kepentingan yang pada akhirnya akan menguntungkan perusahaan.

\section{KESIMPULAN}

Kesimpulan pada penelitian ini adalah Pertama, Profitabilitas tidak berpengaruh signifikan secara parsial terhadap corporate social responsibility disclosure pada perusahaan pertambangan yang terdaftar di BEI periode 2012-2016. Kedua, Leverage tidak berpengaruh signifikan secara parsial terhadap corporate social responsibility disclosure pada perusahaan pertambangan yang terdaftar di BEI periode 2012-2016. Ketiga, Ukuran perusahaan berpengaruh signifikan secara parsial terhadap corporate social responsibility disclosure pada perusahaan pertambangan yang terdaftar di BEI periode 2012-2016. Keempat, Ukuran dewan komisaris berpengaruh signifikan secara parsial terhadap corporate social responsibility disclosure pada perusahaan pertambangan yang terdaftar di BEI periode 2012-2016.

Keterbatasan pada penelitian ini adalah Pertama, Peneliti hanya menggunakan empat variabel independen untuk menguji pengaruhnya terhadap corporate social responsibility disclosure. Kedua, hanya perusahaan pada sektor pertambangan yang digunakan sebagai sampel, sehingga tidak diketahui bagaimana pengaruh variabel independen terhadap variabel dependen pada sektor perusahaan lainnya, seperti jasa, manufaktur, perbankan, 
dan sebagainya. Ketiga, Periode penelitian yang digunakan pada penelitian ini hanya selama lima tahun.

Berdasarkan kesimpulan dan keterbatasan pada penelitian ini maka, peneliti memberikan saran sebagai berikut: Pertama, Bagi perusahaan yang mengimplementasikan corporate social responsibility diharapkan lebih terbuka mengungkapkan kegiatankegiatan yang berhubungan dengan tanggung jawab sosial perusahaan dalam laporan tahunannya. Kedua, Bagi peneliti selanjutnya hendaknya menambahkan atau menggunakan variabel independen lain diluar variabel yang diteliti pada penelitian ini, menggunakan sektor perusahaan diluar sektor pertambangan, sampel yang lebih luas dan tahun pengamatan yang lebih lama pula.

\section{DAFTAR PUSTAKA}

Amalia, D. (2013). Pengaruh Karakteristik Perusahaan Terhadap Corporate Social Responsibility Disclosure di Bursa Efek Indonesia. Media Riset Akuntansi 3 (1). ISSN: 2088-2106.

Asmeri, R., T. Alvionita., and A. Gunardi. (2017). CSR Disclosures in the Mining Industry: Empirical Evidence from Listed Mining Firms in Indonesia. Indonesian Journal of Sustainability Accounting and Management1 (1): 16-22. DOI: 10.28992/ijsam.v1i1.23.

Belkaoui, A., and P.G. Karpik. (1989). Determinants of The Corporate Decision to Diclose Social Information. Accounting, Auditing and Accountability Journal 2 (1): 36-51.

Bowman E. H., and M. Haire. (1976). Social Impact Disclosure and Corporate Annual Reports.Accounting, Organizations and Society 1 (1): 11-21.

Budiman, N. A. (2015). Faktor-Faktor yang Mempengaruhi Pengungkapan Tanggung Jawab Sosial Perusahaan. Jurnal Riset Akuntansi Mercu Buana, 1(1), 14-34. ISSN : 2460-1233.

Chauhan, S., and Amit. (2014). A relational study of firm's characteristics and CSR expenditure. Procedia Economics and Finance 11: 23 - 32. DOI: 10.1016/S22125671(14)00172-5.

Chintrakarn, P., P. Jiraporn, J.K. Kim., and Y.S. Kim. (2016).The Effect of Corporate Governanceon Corporate Social Responsibility. Asia-Pacific Journal of Financial Studies 45. 102-123. DOI: 10.1111/ajfs.12121.

Deitiana, T. (2015).The Determinant of CSR Disclosure of Mining Industry Listed in Indonesia Stock Exchange. Asian Business Review 5 (3): 141-148. DOI: 10.18034/abr.v5i3.664.

Dewi, N.P.M.S., dan I.G.N.A. Suaryana. (2015). Pengaruh Profitabilitas dan Kepemilikan Asing Pada Pengungkapan Corporate Social Responsibility. E-Jurnal Akuntansi Universitas Udayana 13 (1): 84-98. ISSN: 235202-8429.

Dowling, J., and J. Pfeffer. (1975).Organizational Legitimacy: Social Values and Organizational Behavior. The Pacific Sociological Review 18 (1): 122-136.

Felicia, M., dan N.K. Rasmini. (2015). Faktor-Faktor yang Mempengaruhi Pengungkapan Corporate Social Responsibility pada Perusahaan yang Terdaftar di BEI. E-Jurnal Akuntansi Universitas Udayana 12 (2): 143-153. ISSN: 2302-8556.

Gunawan, J. (2013). Determinant Factors of Corporate Social Disclosures in Indonesia. Issues in Social and Environmental Accounting 7 (2): 113-134. ISSN 1978-0591. 
Hidayat, M. (2017). Faktor-Faktor yang Mempengaruhi Pengungkapan Sukarela pada Laporan Tahunan Sektor Perbankan di Bursa Efek Indonesia. Jurnal Dimensi Universitas Riau Kepulauan 6 (1): 151-172. ISSN:2085-9996.

Indonesia, (2009). Undang-Undang No. 32 Tahun 2009 tentang Perlindungan dan Pengelolahan Lingkungan Hidup.

Jensen, M. C., and W.H. Meckling. (1976).Theory of the Firm: Managerial Behavior, Agency Costs and Ownership Structure. Journal of Financial Economics 3 (4): 305360.

Kholiqa, K. R. (2018). Fakta di Balik Temuan BPK soal Freeport. (Diperoleh dari: economy.okezone.com/read/2018/03/25/320/1877626/fakta-di-balik-temuan-bpksoal-freeport/8-2-2018).

Krisna, A. D., dan N. Suhardianto. (2016). Faktor-Faktor yang Mempengaruhi Pengungkapan Tanggung Jawab Sosial. Jurnal Akuntansi dan Keuangan18 (2): 119128. DOI: $10.9744 /$ jak.18.2.119-128.

Lindawati, A.S.L., dan M.E. Puspita. (2015). Corporate Social Responsibility: Implikasi Stakeholder dan Legitimacy Gap dalam Peningkatan Kinerja Perusahaan. Jurnal Akuntansi Multiparadigma 6 (1): 157-174. DOI: 10.18202/jamal.2015.04.6013.

Manurung, E., dan D. Muid. (2015). Pengaruh Karakteristik Perusahaan Terhadap Pengungkapan Tanggung Jawab Sosial. Diponegoro Journal of Accounting 4 (2): 1. ISSN (Online): 2337-3806.

Maulana, F., dan Yuyetta, E. N. A. (2014). Pengaruh Karakteristik Perusahaan Terhadap Pengungkapan Corporate Social Responsibility (CSR). Diponegoro Journal of Accounting, 3(2), 463-476. ISSN : 2337-3806.

Nurfadilah, W., dan Y. Sagara. (2015). Pengaruh Good Corporate Governance, Karakteristik Perusahaan dan Regulasi Pemerintah Terhadap Pengungkapan Corporate Social Responsibility. Akuntabilitas 8 (1): 78-89. P-ISSN: 1979-858X. DOI: 10.15408/akt.v8i1.2763.

Pradnyani, I. G. A. A., dan Sisdyani, E. A. (2015). Pengaruh Ukuran Perusahaan, Profitabilitas, Leverage, dan Ukuran Dewan Komisaris Pada Pengungkapan Tanggung Jawab Sosial Perusahaan. E-Jurnal Akuntansi, 384-397. ISSN: 23028556.

Priyasidharta, D. (2016). Bupati Banyuwangi Akan Tegur Perusahaan Tambang BSI. (Diperoleh dari: https://nasional.tempo.co/read/797464/bupati-banyuwangi-akantegur-perusahaan-tambang-bsi/8-2-2018).

Purbowati, R., and Mutiarni, R. (2017). Pengungkapan Corporate Social Responsibility Ditinjau Dari Karakteristik Perusahaan. Jurnal Akuntansi dan Bisnis: Jurnal Program Studi Akuntansi, 3(2). DOI: 10.31289/jab.v3i2.1236.

Riantani, S., and H. Nurzamzam. (2015). Analysis of Company Size, Financial Leverge, And Profitability and Its Effect to CSR Disclosure. Jurnal Dinamika Manajemen 6 (2): 203-213. DOI: 10.15294/jdm.v6i2.4308.

Sari, W.N., dan P. Rani. (2015). Pengaruh Kepemilikan Institusional, Kepemilikan Manajerial, Return On Assets (ROA) dan Ukuran Perusahaan Terhadap Pengungkapan Corporate Social Responsibility (CSR) Pada Perusahaan Manufaktur Yang Terdaftar Di Bursa Efek Indonesia Periode 2011-2013. Jurnal Akuntansi dan Keuangan FE Universitas Budi Luhur 4 (1). ISSN: 22527141. 
Sembiring, E. R. (2005). Karakteristik Perusahaan dan pengungkapan tanggung Jawab Sosial: Studi Empiris pada Perusahaan yang Tercatat di Bursa Efek Jakarta. Simposium Nasional Akuntansi 8. Solo.

Situs (Website) Resmi Bursa Efek Indonesia: http://www.idx.co.id

Solikhah, B., dan Winarsih, A. M. (2016). Pengaruh Liputan Media, Kepekaan Industri, dan Struktur Tata Kelola Perusahaan Terhadap Kualitas Pengungkapan Lingkungan. Jurnal Akuntansi dan Keuangan Indonesia, 13 (1), 1-22. DOI: 10.21002/jaki.2016.01.

Sunaryo B. A., dan H. M. K. Mahfud. (2016). Pengaruh Size, Profitabilitas, Leverage dan Umur terhadap Pengungkapan Tanggung Jawab Sosial Perusahaan (Studi Empiris Perusahaan Manufaktur yang Listing di BEI TAHUN 2010-2013). Diponegoro Journal of Management 5 (2): 1-14. ISSN (Online): 2337-3792. 